\title{
BEHAVIORAL MODELS IN ECONOMICS AS A FRAMEWORK FOR INDIVIDUAL ADAPTATION TO THE INSTITUTIONAL ENVIRONMENT
}

\author{
Dragan Petrovic*, Zoran Stefanovic and Ivan Markovic \\ Faculty of Economics, University of Nis, Nis, The Republic of Serbia
}

Behavioral models are a useful instrument of the analysis of interdependent impacts of the institutional structure and macroeconomic trends. Their role, among other things, is reflected in presenting the advantages and disadvantages of different interpretations of economic reality, associated with the subjective perceptions of the possibilities of the adaptation of economic actors to the requirements of the existing institutional structure. Having in mind the fact that the economic decision-making process is an integral part of macroeconomic and broader social ontology, as well as the different opinions regarding the basic features of behavioral models, the subject of this work is focused on trying to determine their theoretical relevancy and practical foundation. Special attention is paid to the phenomenon of the realism of behavioral models in order to analyze their instrumentalist importance for the implementation of the policy of asymmetric paternalism in conditions of uncertainty.

Keywords: behavioral models, institutional structure, macroeconomics, paternalism

JEL Classification: D03, E03, B29, B41, P29

\section{INTRODUCTION}

Using a method assumes the existence of a certain explicit or implicit notion of reality (ontology), at least to the extent that the nature of reality is such that it may be the subject of knowledge. The ontological basis, therefore, refers to what exists, i.e. to the nature of things and events. Thanks to

* Correspondence to: D. Petrovic, Faculty of Economics, University of Nis, Trg kralja Aleksandra Ujedinitelja 11, 18000 Nis, Republic of Serbia; e-mail: dragan.petrovic@eknfak.ni.ac.rs ontological assumptions, it is possible to identify certain differences between various methodological procedures. The reason for methodological confrontation should be sought in terms of the functioning of multidimensional and layered social reality, which in order to be adequately described and explained requires using various research approaches, methodologies and analytical techniques (Samuels, 1998). The multiplicity of methods and theories (Dow, 2008) testifies to the challenges and potentials of scientific research, 
taking into account the fact that each research question is specific enough to require a special way of research. In this case, a blind struggle for "one best answer" would have led researchers astray. Hence, ontological "sensitivity" is a necessary component of any serious attempt to differentiate theoretical approaches and their inherent methodological procedures (Dobusch \& Kapeller, 2012, 1042).

To understand economic ontology as the basis of economic knowledge is of great importance for the philosophy and methodology of economic science. In modern economics, there is no single generally accepted approach to economic ontology. In accordance with this ontological context, different viewpoints should be treated, among which those related to micro-/macro-, static/dynamic, shortand long-term, endogenous/exogenous factors etc. should be mentioned. When the level of the observation and analysis of economic phenomena is concerned, the relationship between reality and its presentation is particularly interesting in the context of considering the basic features of macroeconomic ontologies as part of a wider social ontology (Lawson, 2015).

Starting from a need for a more realistic interpretation of economic and social ontology with respect to obvious differences in the structure of the observations of real economic processes, the subject of this paper is the highlighting of the importance of behavioral models for an improvement of the understanding of the actual characteristics of the economic environment.

The main objective is to highlight their ontological relevance through the analysis of the key characteristics of behavioral models and consider the benefits of the relativization of the assumption about the perfect rationality of economic actors.

Accordingly, the basic hypothesis is: The behavioral models based on the assumption about the heterogeneity of the economic environment and the complementarity of the goals of the state and economic entities represent a proper instrumental framework for the implementation of the policy of asymmetric paternalism. By abandoning the mechanistic understanding of the process of economic decision-making and insisting on empirically established data on behavioral "anomalies" and psychologically determined deviations from the rational choice model, the message is directed towards about the state regarding the need for designing rules and regulations in order to mitigate the extent of the "irrationality" of decisions on the use of resources.

The basis of the approach in this research is represented by the theoretical, structural analysis of the subject matter of the research derived from the elaboration of available sources. This means that, in order to test the said hypothesis, empirical studies conducted by various authors who have dealt with this issue will be used in the research. Then, by combining the analytical economic analysis with the descriptive and qualitative economic analysis, general conclusions will be derived about the existence of the "irrational" forms of economic behavior and the need for a certain involvement of the state in terms of the implementation of the policy of asymmetric paternalism.

Structurally, the paper is divided into four sections. After the Introduction, the basic features of the behavioral models, with a special emphasis on the relevance of the ontological assumptions about the uniformity/heterogeneity of the economic environment and the degree of the complementarity of the goals of the state and economic entities will be discussed. In the second section of the paper, the alternative concepts of ontology that, according to the subject matter of this research, affect the level of the rationality of economic agents, the models of economic decision-making and the comprehension of the functioning of the economic environment will be the subject matter of consideration. The evaluation of the differences between mainstream economics and the secondary streams of economic thought will take into account both the logical and 
the empirical assessment criteria for the relevance and sustainability of alternative interpretations. In the third section, the research study will focus on behavioral economics and its representatives' insisting on the fact that reality abounds with the examples of irrational behavior, which is primarily associated with numerous psychological limitations and "anomalies". The practical importance of the identification of the ontological structure of the behavioral models in terms of the support they provide in designing the instrumentalist support measures of asymmetric paternalism will be the subject matter of discussion in the fourth section of the paper. In the conclusion, the research study will formulate the final stance on the initial hypothesis, as well as some open questions relevant for future research.

\section{BASIC FEATURES OF BEHAVIORAL MODELS IN THE MACROECONOMIC CONTEXT}

The relationship between economic reality and its presentation in science is extremely complex. When economic ontology is concerned, the ontological status of individuals and society is a particularly delicate problem. On the one hand, there is the concept of atomistic social ontology (Zwirn, 2007), according to which the preferences and characteristics of an individual are preformed and independent of the context. On the other hand, there is the ontological concept that recognizes the interdependent interaction of individuals, evaluating the impact of institutions on economic behavior. Within this social ontology, the individual and the social characteristics of the system are declared equally relevant, which raises the question of establishing relationships and interaction between and the potential compliance of the objectives of the state and economic actors.

In the context of interpreting the aforementioned relationship, the two aspects of economic reality are of special importance: the degree of the homogeneity of the economic environment and the complementarity of the objectives of economic entities and the state (Likhachev, 2013, 789). The homogeneity of the economic environment assumes that all or the majority of economic actors use the identical decision-making procedure, which can be presented as the general behavioral model. In this case, the optimal strategy for the determination of the government regulation is substantially simplified, since the reaction of economic agents exclusively depends on their functional role within the system. When economic actors' behavior is seen as homogenous, the identical efforts aimed at achieving the maximization of individual goals, the implementation of the state regulation depends on the assumed degree of the complementarity of the goals of the state and economic entities. If it is assumed that this level is quite high, the task of the state is reduced to searching for the optimal variant of regulation, which simultaneously maximizes the target functions of the state and economic agents. If the degree of the complementarity of the goals is insignificant, the state is to create a system of contra-stimulations (which limit the possibilities of maximizing the objective function of economic agents) in order to mitigate the effect of the limiting factors for the purpose of the maximization of its own objective function.

Assuming the diversity of the economic environment, i.e. allowing for the possibility of the existence of different models of decision-making, the diverse reactions of economic actors to the measures designed and implemented by the state are logical to expect. In such a theoretical approach, it is possible to group economic actors not only according to their functional characteristics, but also according to their decision-making models and their potential reactions to the activities carried out and measures taken by the state. In this case, the choice of the optimal macroeconomic strategy depends on the structural characteristics of the inhomogeneous economic environment the assumed level of the non-homogeneity of the operations performed by economic actors. 


\section{ALTERNATIVE CONCEPTS OF ONTOLOGY IN ECONOMICS}

The assumption about the total homogeneity of the economic environment is one of the key features of neoclassical economic theory, as well as of all of its modifications embodied in monetarism, rational expectations and real economic cycles. The aforementioned homogeneity is based on the universal principle of maximizing rationality, described in the model of the "representative agent". This approach is essentially designed to postulate the "representative individual" or "representative firms" on the basis of aggregated information on decision-making processes (Simon, 1992, 41). This approach does not view the operation and procedures of an economic activity from the perspective of the complementarity of the objectives of economic actors and the state. State intervention is instead seen as the hindering factor for achieving optimal economic parameters in the long run. The relationship between the state and businessmen is treated as a kind of an antagonistic "game", in which the gains of the one side are the equivalent to losses of the other (Likhachev, 2013, $790)$, which usually results in the reduction in overall social welfare. Therefore, the minimization of the discretionary role of the state is proposed through the establishment of an institutional regulatory framework and a stabilization policy.

For neoclassical theory, the principle of rationality has both an analytical and a normative meaning, which manifests not only in the description and explanation of the observed phenomena, but also in assessing alternative options by the "good/ bad" terms. The mere assertion that individuals always act rationally is inextricably linked to the presumption that they know what is in their best interest and that they know it better than anybody else does. Accordingly, this presumption is both normative and positive: individuals should act and always act in their best interest. In this way, the question of "how to decide" becomes important, which, inter alia, contributed to the emergence of normative decision theory in the mid-twentieth century. Unlike descriptive theory aimed at a positive description, normative decision theory deals with the concept of the rationality and logic of decision-making, thus being aimed at how they should look (Milićević, Pavličić \& Kostić, 2007, 147)

In contrast to neoclassical economic theory, the alternative stream of the understanding of economic ontology is based on the assumption about the heterogeneity of the economic environment. This viewpoint claims that individuals cannot be seen as uniformed agents not differing in terms of their individual preferences, demands and aspirations. Instead, it insists on the fact that they are prone to the non-identical understanding of the functioning of the economic environment and that they are characterized by an uneven level of educational and technological capabilities. Individuals are not similar neither in terms of their preferences nor in terms of opportunities, from which follows that the explanation of economic behavior needs something beyond a mere postulate of rationality (Blaug 1992, 232). In addition to the above, the real circumstances suggest that in order to understand an individual's behavior, it is necessary that the influence of habits, tradition, inertia, imitation etc. should be considered.

While not neglecting the general "rational" direction of humans, one still needs to be very cautious when the justification for the thesis of universal egoism inherent in the so-called "homo oeconomicus" of the neoclassical approach is concerned. The assumption about the real existence of "relational man", who is not in any case an absolute uncompromising egoist, is probably more realistic instead. There are, for example, opinions that requirements for the continuous and often ruthless process of enlarging capital cannot only be seen as a product of rational logic, but also as a product of the fact that the owners of capital are forced to accumulate it, primarily due to strong competition inherent in open markets. Observed from the family perspective, it is indisputable that 
some households primarily tend to increase their material wealth. For other households, however, a source of satisfaction can be an idyllic and relatively modest lifestyle; there are households devoted to achieving broader social interests, whereas there are those believing that their altruistic sacrifice performs a certain social mission. From the above, it follows that people have the ability, and often a tendency, to understand and respond to other people's troubles. In the field of the economic activity, in addition to the rational motives, they are ready to conform to some other standards of behavior, such as trust, affection, empathy, etc. (Олейник, 1999, 140).

The idea of rationality in the neoclassical model is based on the assumption that the economic action takes place on the basis of the possession of all necessary information needed for the correct evaluation of alternative choices and their consequences. In practice, however, the behavior directed towards the choice of the most suitable ways of and means for achieving objectives is faced with many difficulties. Unfortunately, people live in the world of uncertainty, which raises the question of decision-making in the circumstances of a lack of the knowledge of the final consequences of decisions. It is certain that in the conditions of the existence of a number of limiting factors people develop models of subjective choices, which are deprived of a foothold in the abundance of perfect pieces of information. The absence of a single model further contributes to increased uncertainty and, therefore, different economic actors manifest a tendency to take risks, depending on the subjective experience of the specific content from the external environment. The volatility of the subjective perceptions of satisfactory economic outcomes is associated with a variety of possible decisionmaking procedures leading to different levels of rationality. If an individual wants to be rational, he must carefully approach the decision-making procedure in terms of a detailed analysis and the processing of necessary pieces of information. On the other hand, an individual who does not have enough time and money will use less complex algorithms. It turns out, therefore, that the achievement of full rationality is an extreme case, which, in the decision making process, requires using the perfect algorithm designed with respect to a huge number of limiting factors. In all other cases, the decision output is the result of the imperfect implementation of the decision-making algorithms that are nothing else but the practical realization of limited rationality.

Although risking to find themselves under suspicion of abandoning the very science of economics (Hodgson, 1988, 74), those who raise the issue of rationality still have quite a reasonable explanation supportive of the relevance of their research efforts. In this respect, pragmatic interpretation should be emphasized, according to which only by contesting the maximizing of rationality can some steps be taken in order to direct economic actors' behavior towards encouraging this very same rationality. This line of thinking, among other things, can explain the complementarity of the goals of the state and economic actors. When one recognizes that people can make choices inconsistent with their "best" interests, the opinion that the state can help people make better and more informed decisions becomes relevant.

Taking into account numerous negative experiences of having had the state involved, as well as those of the frequent absence of the expected effects of its measures, the clarification of state intervention within the framework of institutionalism and behavioral economics appears to deserve special attention. Unlike neoclassical economics, according to which people as living beings have innate individual preferences and motives, institutionalists believe that the roots of human action must be sought in the functioning of institutional structures (Dugger, 1979, 903). It is implied that institutions are not merely the constraints that a rational actor must take into account in its optimizing calculus, but as basic regulators of relations between 
people, they are in fact the very presumption of rationality (Олейник, 1999, 140). More specific recommendations regarding the overcoming of the problems caused by irrational behavior are provided by behavioral economics.

Behavioral economics is based on the premise that the thought processes and people's decisionmaking are based on the two types of procedures: intuition and reasoning, which are also known as System 1 and System 2. The operations of System 1 are fast, automatic and associative and do not require a significant mental effort and are often emotionally loaded. They are managed by habits and are hard to change. The operations of System 2 are slow, serial, require an effort and are managed consciously. They are relatively flexible and subject to rules. Most decisions are the product of intuitive thinking, given the fact that people are not habituated to invest too much effort in making decisions. According to the model of rational behavior, one's cognitive system is actually a mixture of the aforementioned two mechanisms: it possesses the infallibility of System 2 and a low cost advantage inherent in intuitive thinking. While maintaining the aforementioned description of the human cognitive apparatus, behavioral economics indicates its limits and shortcomings in the field of human decision-making in real situations (Kahnemann, 2003a; Stefanović, 2016). Human behavior actually displays systematic deviations from the conventional model of economic orthodoxy.

During the 1970s, the founders of this approach, D. Kahneman and A. Tversky, launched a research study aimed at examining the deviations of people's actual beliefs and choices in relation to those predicted under the model of rational choice. Specifically, this research study initially critically reconsidered the basic assumptions of conventional economic theory, according to which agents are rational and selfish and have stable preferences (Kahnemann, 2003b, 162). Although their contributions were aimed at the psychological scientific community, they have drawn a considerable attention of economic theory.

This approach obtains technical and methodological support from experiments, although in recent times it has also used field research, computer simulations, etc. Regarding the method, there are significant similarities with the related research orientation, known as experimental economics. However, unlike behavioral economics, which has more diversified methodological techniques, the latter approach identifies itself only with the method of experimentation. There is one significant difference between behavioral and experimental economics. Behavioral economics detects deviations from the model of rational choice in the real world in order to obtain actors' real behavior in accordance with its prescriptions. For experimental economists, if an experiment proves a deviation in an individual's behavior in relation to the neoclassical model, it does not mean that such behavior is essentially irrational, but rather that the research study actually started from the wrong model of rationality. Although irrational in terms of the model of rational choice, individuals' behavior is rational in terms of their economic environment. Their behavior is not neoclassically rational, but environmentally rational (Smith, 2005, 135-150; Stefanović, 2016).

\section{BEHAVIORAL ERRORS}

Behavioral economics does not interpret economic behavior in accordance with the standard model of rational choice. Its representatives insist on the fact that reality abounds with the examples of irrational behavior, which is primarily associated with numerous physical limitations and anomalies. In this regard, the most frequently mentioned behavioral imperfections are those relating to inconsistency in terms of discounting, the variability of psychological and emotional states, the context dependence, a lack of self-control, 
excessive optimism, a status quo bias, etc. (Rizzo \& Whitman 2009, 932-943).

Hyperbolic discounting. There is a well-known fact that individuals prefer present goods and that, therefore, they are willing to sacrifice a greater amount of future goods in order to consume a smaller amount of the same good at the present time (Wright \& Ginsburg, 2012, 1043). The proportions of such conversions, however, are the result of subjective norms connected to the evaluation of time in terms of enjoying the benefits of the current consumption. Since the subjectively shaped estimates may differ significantly among actors, it can happen that in their making decisions on the use of resources, individuals begin from various discount rates. Thus, for example, a discount rate is by rule low when patient persons are concerned, whereas it is generally high for the impatient. High impatience is accompanied by a high shortterm discounting rate in those decisions that are supposed to immediately bring certain benefits, whereas the costs accompanying the process of decision-making gradually become due over time. Unfortunately, such an approach can lead to negative phenomena, such as the postponement of making important decisions, forming portfolios of mutually exclusive financial instruments (when, for example, individuals use credit cards for which they pay high interest rates while buying securities with lower yields), too much borrowing, low savings, etc. (Kapeliushnikov, 2015, 87).

The psychological state. The decision-making process is greatly influenced by individuals' psychological states, which can result in significantly different effects from those that would have been produced if the actors were guided by the elementary norms of rational behavior. In some affective, biological "hot" and "burning" states, individuals are prone to making hasty decisions, which prove to be wrong and very "expensive" over time, and it is impossible to return to the former state after adopting them (Camerer, Issachoroff, Loewenstein, O'Donoghue \& Rabin, 2003, 1238; Rizo \& Whitman, 2009, 929).
In such cases, an individual usually overestimates potential short-term benefits, simultaneously ignoring a possible long-term damage and the high cost of making such decisions. For instance, in a state of disappointment caused by initial financial results and the fears that they will not be able to cope with competition, beginning entrepreneurs may decide to end the operation and close their companies, which in the long run may turn out to be a completely wrong move.

The effect of availability. These are the errors that occur when individuals attach too much importance to easily accessible or key information. It is widely known that, chronologically speaking, the first experience (the primacy effect) or the last experience (the recency effect) are easier to evoke than those taking place between them (McFadden, 2003, 186-187). For example, if they have recently learnt that a well-known company has been undergoing liquidation or that there is a strike in a big company, many people will come to a conclusion that bankruptcies and strikes have lately taken hold. This, however, does not have to be supported by statistical data. Perhaps more complete research may lead to the crude fact that these occurrences have always happened and that they just reflect the complexity of the market economy and its functioning (Petrović, 2014, 199).

Errors associated with maintaining the status quo. People tend to be reserved to a certain extent about everything novel, even in cases when such a novelty can bring significant benefits or when the costs associated with "parting" with the old are relatively low. One of the reasons for such a sensitive evaluation of changes is the fact that people have quite an emotional attitude towards their work and the results of their acting, which, however, is not the case when they themselves are not the actors of the observed actions and events. Another reason is their hesitation, delays in making important decisions for some future times. Finally, people have an aversion towards a loss, which is why, when comparing equivalent amounts, they 
rather ascribe a relatively larger negative value to potential costs than they are ready to make a positive assessment of the potential benefits (Kapeliushnikov, 2015, 88).

Errors associated with optimism and pessimism. Depending on whether people are too confident, or, in turn, characterized by a lack of confidence, errors arise and, within behavioral economics, they are associated with optimism and pessimism. Errors caused by optimistic thinking arise as a result of ignoring a certain probability of the occurrence of undesirable events (Wright \& Ginsburg, 2012, 1043), which may cause serious, often irreversible damage for an individual. For instance, an optimist can take too big a risk by investing assets in securities with a high rate of return. However, due to its dynamism and mobility, the secondary capital market is a typical area where there is a high level of uncertainty, which an individual must be aware of when deciding on the purchase of securities. On the other hand, errors on the basis of pessimism are characteristic for people unsure of themselves, for those who are therefore prone to exaggerating the probability of the occurrence of undesirable events. The consequence of this is excessive prudence, which usually results in avoiding any risks when investing is concerned.

Context dependence. This anomaly occurs in two different forms. One of them is known as the framing effect, when decisions are made on the basis of the impact of a less important feature of the particular situation or phenomenon. Accordingly, an individual is prone to choosing certain options depending on the order of their appearance and the manner in which their selection is presented. For example, more people support the economic policy when the reasoning for the envisaged measures highlights the importance of the employment rate than in a case when the unemployment rate is the spotlight (Druckman, 2001). In the case of a particular company, the workers will express one opinion when it is announced that the goal of the purchase of modern equipment is to make an increase in labor productivity, whereas they will probably opine differenty when it is stated that such new equipment is purchased for the purpose of reducing labor costs. Context dependence can also be seen through a possibility of the evaluation of available alternatives on the basis of a comparison with certain reference values, amounts or quantities. The point of reference used to make a particular comparison can be a result of personal experience, as well as of certain factors originating from the environment. For instance, if a business owner is measuring his success in absolute terms, he may be dissatisfied with the company's operations, believing that he did not achieve the desired results. In another context, however, based on comparisons with the business results achieved by the companies in his environment, he may even be relatively satisfied with the achieved results (Petrović, 2014, 199).

\section{REALISM OF BEHAVIORAL MODELS IN FUNCTION OF PATERNALISTIC MEASURES AND STATE INTERVENTION}

The identification of behavioral anomalies confirms the fact that economic behavior is often inconsistent with the assumption about the rationality hypothesis and maximizing behavior. Therefore, special attention is deserved by the efforts to replace the established understanding of the concept of rational economic behavior with a new, more realistic description of human behavior based on the assumption about limited rationality. Hence the need for the elaboration of behavioral models with larger instrumentalist importance in terms of the support of the adoption of the government measures aimed at alleviating the problems caused by the non-rational aspects of decision-making. The assumptions of the behavioral models based on empirically established facts relating to more or less rational/irrational forms of behavior and different decision-making procedures provide strong support to the creation of instrumentalist 
paternalistic measures and interventions. The very recognition that people can make choices inconsistent with their best interests contributes to the development of the idea about how a paternalistic-oriented state can help people make "better" and more informed decisions.

The instruments of the state policy are a complex combination of legislative and administrative restrictions, taxes, provisions of necessary information and the established ways of persuasion and manipulation with the "architecture" of choice. Among the aforementioned forms of state interference in the process of making individual decisions, the "strongest" are believed to be those introducing explicit prohibitions of and restrictions on economic choices. Limiting individual behavior is justified when the irrationality of economic entities is so much pronounced that it is almost impossible to correct it by using "soft" paternalistic measures. In this regard, it is proposed that legislation should be established in all areas characterized by a high risk of the irrational behavior of economic entities. For example, it is possible to introduce a tax on a "sin" (alcohol, smoking, gambling), junk food and alcoholic beverages (fatty foods, carbonated beverages, etc.) (O ‘Donoghue \& Rabin, 2003, 190-91).

There is certainly a more favorable solution to directing restrictions and prohibitions, which is based on the supporting measures of "asymmetric paternalism", essentially associated with the above-mentioned assumptions about the heterogeneity of the economic environment and the complementarity of the goals of the state and economic entities. Asymmetric paternalism associates the achievement of economic objectives through different decision-making procedures and their inherent levels of rationality (Thaler \& Sunstein, 2008, 9). Decision-making problems are particularly pronounced in the cases in which it is necessary that a complex decision should be passed. Individuals can then have problems regarding the understanding of the situation they have found themselves in, which is the reason why they do not react in the same way to stimuli from the environment. The doubt that all men always and by rule make decisions in their best interests (Camerer et al, 2003, 1217) is accompanied by the idea that people need help in order not to inflict damage to themselves with their own decisions. Accordingly, the opinion has matured that that the involvement of the state should focus on the prevention of the errors made by "less rational" individuals, whereas these measures should not impose costs on those who make decisions based on the application of the more sophisticated decision-making algorithms, taking into consideration a large amount of necessary information. The task of the asymmetric paternalism is, therefore, to "gently" direct individuals' behavior towards the rational model, stimulating sufficiently less rational individuals to improve their choices, simultaneously not harming the interests of rational individuals (Camerer et al, 2003, 1219). The goal is not to change behavior, but rather to direct it so that it could contribute in the most efficient way to the realization of individual interests.

As an illustrative example of the asymmetric paternalism and selective mitigation of irrational decisions, the so-called legal determination of the "cooling-off period" in the form of the two possible alternatives may be mentioned (Camerer et al, 2003, 1240). The first alternative allows individuals an opportunity to postpone the adoption of certain decisions after a "cooling-off period". Another option concerns making immediate decisions on the execution of economic transactions, with a possibility that, during the "cooling-off period", they can be subject to change. Let us now take an example determined by a possibility of a threeday cooling-off period when buying a new car is concerned. According to the first option, when an individual is signing a contract of the purchase of a car, he can wait, for example, for three days before he can take the car (during which period he can change his mind) - the case of the ex ante "coolingoff period". Another option implies taking the car 
immediately, provided that it can be turned back within three days - the case of the ex post cooling-off period. Thanks to this measure, rational individuals are imposed minimal costs - the costs of a delay in purchasing a car for a few days. At the same time, the "cooling-off period" protects those less rational, who make decisions in the so-called "hot state".

Some proof of how asymmetric paternalism can be helpful in assessing the effectiveness of government measures and policies can be provided by the concept of "default options" (Thaler \& Sunstein, 2008). The point of using this institution is to help individuals overcome ambiguous situations specific to certain important decisions. Empirically, the majority of people are found to pay more attention to the current situation and current consumption, simultaneously significantly sacrificing their future needs. Therefore, instead of a freedom of choice regarding a decision on the voluntary allocation of work income for pension insurance, it is more logical to "call out" the government to make a choice for and instead of an individual. A well-known solution in this sense, present in many national legislations, is the one relating to automatic participation in savings plans (Rizo \& Whitman, 2009, 914; Thaler \& Sunstein, 2003, 1172), which excludes errors associated with inconsistency, the weakness of will, hyperbolic discounting, etc. Participation by default primarily starts from the problem of inconsistency over time, which indicates the need for people's future commitment to the postured plans. In the case of savings in the pension funds, this requires finding ways to ensure employees' consent to deductions from their salaries prior to payment. Thus, the money is deposited into the pension fund account, whose mission is to invest in their name.

One of the instruments of asymmetric paternalism also concerns the compulsory disclosure of certain information when concluding valuable contracts connected, for example, with crediting, mortgage, leasing, as well as the purchases of high-risk goods and services. In this regard, there is a belief that the sellers of health harmful products are obliged to provide citizens with detailed information about certain risks (with explanations, statistical data, etc.) (Kapeliushnikov, 2015, 93). The information mandatory disclosure policy is particularly effective when the issuance of consumer loans is concerned. Since "wrong" behavior is widespread in the financial sphere, which produces high damage, it is recommended that consumers should be properly informed about all banking products. This need for information cannot only be reduced to the fulfillment of the justified demands for the disclosure of all the relevant information related to the process of lending. It is more important that the conclusion of loan agreements, in which the mandatory elements of standard banking products will have an advantage over the implicit credit clauses, should be receive support.

Starting from the fact that the state has discretion to establish formal institutions and design paternalistic measures and interventions, its role in the context of economic and social development can be considered as crucial (Petrović, 2015, 353). Due to the accumulated social and economic problems, as well as to the slow acceptance of the "market" norms of behavior, it seems that the state of Serbia and its political authorities are being faced with the enormous tasks of institutional design, which will probably affect the models of behavior of the relevant domestic actors. The process of the accession of Serbia to the European Union is a type of the framework for the undertaking such a reform.

Having in mind all the challenges that the state of Serbia is being faced with, it seems quite reasonable that, in the implementation of its program, the government should identify the key reasons for economic actors' "irrational" behavior, with the intention of taking the full account of the tendency shown by the majority of the population to commit behavioral anomalies, within the process of conceiving and designing activities towards meeting the membership criteria of the EU. As a 
reminder, during the 2000s, the holders of political power and a large number of the citizens of the Republic of Serbia showed, to express it in the language of behavioral economics, a psychological tendency to make errors associated with optimism and hyperbolic discounting. Namely, an atmosphere was created that the country was at the door of the European Union and that the benefits of the membership in this international economic integration are within citizens' reach. The atmosphere exuded the euphoria caused by the expectations of leaving the Balkan zone of poverty, which resulted, among other things, in the numerous behavioral anomalies associated with the inconsistency and high rate of discounting. The pronounced impatience was followed by the adoption of the decisions supposed to immediately bring certain benefits, whereas the costs accompanying the decision-making process would gradually become due over time. In order to enrich themselves as quickly as possible, too confident entrepreneurs recklessly resorted to loans and excessive investment, ignoring the possibility of the occurrence of undesirable events. The citizens of the Republic of Serbia also engaged themselves in imprudent borrowing, which, in addition to the effects associated with optimistic thinking and hyperbolic discounting, can also be associated with the influence of the "hot" psychological condition. In fact, after a long credit abstinence during the 1990s, with the opening of transitional changes, the arrival of foreign banks and the expansion of their numerous financial products, a large number of Serbian citizens could hardly wait to solve their housing issues, replace their old vehicles, go on vacation, buy new furniture, etc. These borrowings were often done without adequate information about the cost of a consumer credit, the costs of the processing and administration, the interest rate for using credit cards (i.e. the permitted and the prohibited "in the red" status) which, along with the numerous hidden fees and charges contributed to a sharp increase in the citizens' credit indebtedness.
The tendency to commit behavioral failures was also a feature of the political power holders. The excessive expectations regarding the financing of the projects from the pre-accession funds and the obtaining of significant resources from the Regional Development Fund and the Agrarian Fund of the European Union probably influenced the hasty adoption of certain decisions with long-term harmful effects. Within this context, the measures relating to the liberalization of the market, which Serbia was committed to when concluding the Stabilization and Association Agreement with the European Union, can be especially interesting. Accordingly, harmonization starts from the following areas: the protection of competition and the control of the allocation of state aid (subsidies), intellectual property rights, public procurement, standardization and consumer protection. Once the SAA entered into force, the harmonization obligation spread to the other areas of the acquis. The Interim Agreement, which came into force in January 2009, planned the creation of a free trade zone between Serbia and the EU for a period of six years. The deadline for the liberalization of trade appears to have been too optimistically determined in relation to the ability of the Serbian industry and agriculture to adapt to free trade, regardless of Serbia's citizens' and politicians' impatience with a faster completion of the reforms and accession to the European Union.

In contrast to the mood that prevailed during the first decade of the twenty-first century, the euphoria regarding the rapid and cost-effective EU accession has significantly abated after the outbreak of the global economic crisis in 2008. One is under the impression that citizens have become aware of the fact that the membership in any international economic integration does not only bring benefits, but it also generates certain obligations and increased costs as well, whereas in some cases it also brings possible negative occurrences. According to some analysis carried out on the basis of R. M. Solow's model, the costs of Serbia's accession to 
the EU should amount to between 110 and 130 billion dollars in order to reach an average level of the development of the countries of the European Union. The cost of legal harmonization with the EU legislation would amount to about $10 \%$ and the implementation costs to about $20 \%$ of that amount, whereas the largest part of the amount should be used for the modernization of the economy and the infrastructure. This would assume an investment rate of around $30 \%$ of the GDP, the savings rate of about 25\% of the GDP, etc. (Marković \& Petrović, 2016, 157). The awareness of the specificity and high costs of the accession process can easily result in the irrational behavior of citizens and political elites. The specific situation of the economy on the path towards the European Union can stimulate thinking about the non-complementarity of the goals of the state and the population. Therefore, it is realistic to expect an intensification of the psychological anomalies related to maintaining the status quo and pessimistic thinking, as well as the decision-making models based on the influence of the less important characteristics of contemporary phenomena and events. Bearing in mind the fact that, in certain circumstances, people are suspicious of novelties and prone to hesitation and the postponement of making important decisions, is the all the more present lack of the support of the citizens of the Republic of Serbia towards the European Union is not a surprise.

\section{CONCLUSION}

This research study points out the importance of actors' behavioral models in improving the comprehension of the real characteristics of the economic environment. According to the generally accepted standpoint, economic models need to reflect the real economic behavior and conditions of the given economic and social environment. Although there are many cases in which such requirements have been met, the impression is that the formal economic models often fail to find confirmation in empirical research. The key reasons for these observations are, among other things, looking for the sustainability of the mainstream ontology, based on the homogeneity of the economic environment and the complementarity of the goals of the state and economic entities. The assumptions about the universal principle of maximizing rationality and homogenous economic decisionmaking procedures, whereby the relationship between the state and economic actors is treated as a kind of an antagonistic game with conflicting interests, are in accordance with this.

The question of the real merits of the mainstream ontology and the methodology established on its basis makes room for the emergence of alternative ontology comprehensions. In this context, the consideration of the ontological structure is directed towards the elaboration of the behavioral models that challenge the assumption about the complete rationality of economic actors and the homogeneous procedures of economic decisionmaking. The reasons for this approach to the nature of economic behavior should, among other things, be linked to a number of practical pieces of evidence suggesting that real economic behavior often deviates from maximizing the behavior of the "homo oeconomicus".

The potentiation of the empirical research results with respect to the human tendency to behavioral anomalies inspired the emergence of the conflicting reactions on the part of economic theorists. On the one hand, there are those who believe that challenging the issue of rationality is an attack on the "hard core" of economic science. On the other hand, it has been pointed out that insisting on the strong presence of irrational behavior has specific instrumentalist importance, which can also be considered as a message of its own kind of this paper. The recognition that people can make choices inconsistent with their "best interests" is becoming a powerful argument for the inclusion of the state in the development of measures and regulations in order to improve their rationality. 
Accordingly, the hypothesis that the behavioral models are based on the assumption about the heterogeneity of the economic environment and the complementary goals of the state and economic entities represents an adequate instrumental framework for the implementation of the policy of asymmetric paternalism.

The findings presented in this paper suggest a need for a further investigation of the possibilities for the improvement of the behavioral models by taking into account the ontological characteristics of the specific economic and social environments. In this regard, the efforts aimed at a deeper understanding and a thorough analysis of the economic decisionmaking process, including the identification of a number of departures from the rational forms of economic behavior, should be supported. Since the paper initiates a discussion about certain forms of psychological "anomalies" from rational behavior generally present in the behavior of the citizens of the Republic of Serbia within the process of adopting the rules and standards of the European Union, it is reasonable to expect that future research may be directed towards the identification of a wider spectrum of the behavioral "anomalies" that accompany economic behavior in the region. Research efforts focused on a detailed analysis and explanation of the external and internal reasons for irrational behavior could constitute a suitable basis for designing the measures of asymmetric paternalism that the Republic of Serbia should conduct within its strategy of institutional adaptation to the demands of the market economy.

\section{REFERENCES}

Blaug, M. (1992). The Methodology of Economics or How Economists Explain, Second Edition. Cambridge: Cambridge University Press.
Camerer, C., Issachoroff, S., Loewenstein, G., O’Donoghue, T., \& Rabin, M. (2003). Regulation for conservatives: Behavioral economics and the case for asymmetric paternalism. University of Pennsylvania Law Review, 151(1), 1211-1254.

Camerer, C. F., \& Loewenstein, G. (2004). Behavioral economics: Past, present, future. In C. F. Camerer, G. Loewenstein \& M. Rabin (Eds.), Advances in Behavioral Economics (pp. 3-51). New York, NY: Russel Sage Foundation and Princeton University.

Dobusch, L., \& Kapeller, J. (2012). Heterodox united vs mainstream city: Sketching a framevork for interested pluralism in economics. Journal of Economic Issues, 46(4), 1035-1057. doi: 10.2753/JEI0021-3624460410

Dow, S. C. (2008). Plurality in orthodox and heterodox economics. Journal of Philosophical Economics, 1(2), 73-96.

Druckman, J. (2001). Evaluating framing effects. Journal of Economic Psychology. 22(1), 91-101. doi.org/10.1016/S01674870(00)00032-5

Dugger, W. M. (1979). Methodological differences between institutional and Neoclassical economics. Journal of Economic Issues, 13(4), 899-909.

Hodgson, G. M. (1988). Economics and Institutions: A Manifesto for a Modern Institutional Economics. Cambridge, UK: Cambridge University Press.

Kahnemann, D. (2003a). Maps of bounded rationality: Psychology for behavioral economics. American Economic Review, 93(5), 1449-1475. doi: 10.1257/000282803322655392

Kahnemann, D. (2003b). A psychological perspective on economics. American Economic Review, 93(2), 162-168. doi: $10.1257 / 000282803321946985$

Kapeliushnikov, R. (2015). Behavioral economics and the 'new' paternalism. Russian Journal of Economics, 1(1), 81107. doi: 10.1016/j.ruje.2015.05.004

Lawson, T. (2015). Essays on The Nature and State of Modern Economics. London, UK: Routledge.

Likhachev, M. O. (2013). Ontological problems of modern macroeconomics. Middle-East Journal of Scientific Research, 14(6), 788-794. doi: 10.5829/idosi.mejsr.2013.14.6.2137 
Marković, I. i Petrović, D. (2016). Međunarodna ekonomska integracija: Efekti i izazovi članstva. U V. Leković (Ur.), Institucionalne promene kao determinanta privrednog razvoja Republike Srbije (str. 157-173). Kragujevac, Republika Srbija: Ekonomski fakultet Univerziteta u Kragujevcu.

MekFadden, L. D. (2003). Racionalnost za ekonomiste? Ekonomski anali, 156, 169-199.

Milićević, A., Pavličić, D. i Kostić, A. (2007). Odlučivanje u uslovima rizika i teorija izgleda. Psihologija, 40(1), 147-164.

O'Donoghue, T., \& Rabin, M. (2003). Studying optimal paternalism, illustrated by a model sin taxes. American Economic Review, 93(2), 186-191. doi: $10.1257 / 000282803321947029$

Petrović, D. (2014). Behavioral analysis of economic choice: Contribution to improving economic rationality. Facta Universitatis, Series: Economic and Organization, 11(3), 191-205.

Petrović, D. (2015). Behavioral economics - The new approach to designing the paternalistic role of the state in the economy. Teme, 39(2), 345-360.

Rizzo, M. J., \& Whitman, D. G. (2009). The knowledge problem of new paternalism. BYU Law Review, 4, 904968.

Samuels, W. J. (1998). Methodological pluralism. In J. Davis, D. Wade Hands \& U.i Mäki (Eds.), The Handbook of Economic Methodology (pp. 300-303). Cheltenham: Edward Elgar.
Simon, H. A. (1992). Methodological foundations of economics, In J. Lee Auspitz (and other) (Eds.), Praxiologies and the Philosophy of Economics, Series Praxiology (pp. 25-42).

Smith, V. (2005). Behavioral economics research and the foundations of economics. Journal of Socio-Economics, 34(2), 135-50. doi.org/10.1016/j.socec.2004.09.003

Stefanović, Z. (2016). Savremena ekonomska misao: ortodoksni $i$ heterodoksni pravci. Niš, Republika Srbija: Ekonomski fakultet Univerziteta u Nišu.

Sunstein, C. R., \& Thaler, R. (2003). Libertarian paternalism is not an oxymoron. University of Chicago Law Review, 70(4), 1159-1202.

Thaler, R. H., \& Sunstein, C. (2008). Nudge: Improving decisions about health, wealth, and happiness. New Haven \& London, UK: Yale University Press.

Wright, D. J., \& Ginsburg, D. H. (2012). Behavioral law and economics: Its origins, fatal flaws and implications for liberty. Northwestern University Law Review, 106(3), 10331089.

Zwirn, G. (2007). Methodological individualism or methodological atomism: The case of Friedrich Hayek. History of Political Economy, 39(1), 48-80. doi:10.1215/00182702-2006-005

Олейник А. (1999). Институционална экономика, Тема 2. Норма как базовый елемент институтов, Пекция 3. Норми: результат рационалъного выбора или абслодютный детерминант действия? Bопросы эномики, 2, 137-156.

Received on $25^{\text {th }}$ January 2017, after one revision, accepted for publication on $24^{\text {th }}$ April 2017. Published online on $28^{\text {th }}$ April 2017. 
Dragan Petrovic is a professor at the Faculty of Economics, University of Niš, Serbia, where he received his $\mathrm{PhD}$ in General Economic Theory. The areas of his scientific research are economic methodology, institutional economics, macroeconomic theory and political economy.

Zoran Stefanovic is an associate professor at the Faculty of Economics, University of Nišs. The major fields of his research interest are contemporary economic paradigms, the economics of post-socialist transition and the political economy of globalization.

Ivan Markovic is an associate professor at the Faculty of Economics in Niš, where he received his $\mathrm{PhD}$ in the scientific field of International Economics. He teaches the subjects of International Economics, Management of Foreign Trade and International Finance. The key areas of his interest are international economic integration, the European Union, the process of Serbia's accession to the EU. 


\title{
BIHEVIORALNI MODELI U EKONOMIJI KAO OKVIR INDIVIDUALNOG PRILAGOĐAVANJA INSTITUCIONALNOJ SREDINI
}

\author{
Dragan Petrović* Zoran Stefanović i Ivan Marković \\ Ekonomski fakultet Univerziteta u Nišu
}

Bihevioralni modeli predstavljaju koristan instrument analize međuzavisnih uticaja institucionalne strukture i makroekonomskih tokova. Njihova uloga, između ostalog, ogleda se u predočavanju prednosti i nedostataka različitih interpretacija ekonomske realnosti, povezanih sa subjektivnim predstavama o mogućnostima adaptacije ekonomskih aktera zahtevima postojeće institucionalne strukture. Imajući u vidu da je poces donošenja ekonomskih odluka integralni deo makroekonomske i šire socijalne ontologije, kao i različita mišljenja u vezi sa osnovnim obeležjima bihevioralnih modela, ovaj rad usmeren je na pokušaj utvrđivanja njihove teorijske relevantnosti i praktične zasnovanosti. Posebna pažnja posvećena je fenomenu realističnosti bihevioralnih modela, s ciljem da se sagleda njihov instrumentalistički značaj za sprovođenje politike asimetričnog paternalizma u uslovima neizvesnosti.

Ključne reči: bihevioralni modeli, institucionalna struktura, makroekonomija, paternalizam

JEL Classification: D03, E03, B29, B41, P29

\section{UVOD}

Korišćenje metoda podrazumeva postojanje određenih eksplicitnih ili implicitnih predstava o stvarnosti (ontologija), bar do mere do koje je priroda stvarnosti takva da može biti predmet saznanja. Ontološka osnova se, dakle, odnosi na ono što postoji, tj. na prirodu stvari i događaja. Zahvaljujući ontološkim pretpostavkama, moguće je identifikovati određene

* Korespondencija: D. Petrović, Ekonomski fakultet Univerziteta u Nišu, Trg kralja Aleksandra Ujedinitelja 11, 18000 Niš, Republika Srbija; e-mail: dragan.petrovic@eknfak.ni.ac.rs razlike među različitim metodološkim postupcima. Razloge metodološke konfrontacije treba potražiti $\mathrm{u}$ uslovima funkcionisanja multidimenzionalne i slojevite društvene realnosti, koja, da bi bila adekvatno opisana i objašnjena, zatheva primenu različititih istraživačkih pristupa, metodoloških i analitičkih tehnika (Samuels, 1998). Brojnost metoda i teorija (Dow, 2008), svedoči o izazovima i potencijalima naučnog istraživanja, pri čemu treba voditi računa o tome kako je svako istraživačko pitanje dovoljno specifično da zahteva poseban način istraživanja. $U$ ovom slučaju, borba za jedan najbolji odgovor odvela bi istraživače na pogrešan put. Otuda je ontološka 
osetljivost neophodna komponenta svakog ozbiljnog pokušaja diferenciranja različitih teorijskih pristupa i njima imanentnih metodoloških postupaka (Dobusch \& Kapeller, 2012, 1042).

Za filozofiju i metodologiju ekonomske nauke od izuzetnog je značaja razumevanje ekonomske ontologije, jer predstavlja osnovu ekonomskog znanja. U savremenoj ekonomskoj nauci nema jedinstvenog i opšteprihvaćenog pristupa ekonomskoj ontologiji. U skladu s tim, treba tretirati ontološki kontekst suprotnih gledišta, među kojima treba pomenuti one koji se odnose na mikro - makro, statika - dinamika, kratki - dugi rok, endogeni - egzogeni faktori, i sl. Kada je reč o nivou posmatranja i analize ekonomskih pojava, odnos između realnosti i njene prezentacije posebno je zanimljiv $\mathrm{u}$ kontekstu sagledavanja osnovnih obeležja makroekonomske ontologije kao dela šire socijalne ontologije (Lawson, 2015).

Polazeći od potreba za što realističnijom interpretacijom ekonomske i socijalne ontologije, uz uvažavanje evidentnih razlika u strukturi zapažanja realnih ekonomskih procesa, predmet istraživanja u ovom radu je da se ukaže na značaj bihevioralnih modela za unapređenje razumevanja stvarnih karakteristika ekonomske sredine.

Osnovni cilj je da se analizom ključnih obeležja bihevioralnih modela istakne njihova ontološka relevantnost i sagledaju prednosti relativiziranja pretpostavke o savršenoj racionalnosti ekonomskih aktera.

Shodno opredeljenom predmetu i postavljenom cilju istraživanja, osnovna hipoteza rada je: Bihevioralni modeli, bazirani na pretpostavci o raznorodnosti ekonomske sredine i komplementarnosti ciljeva države i ekonomskih subjekata, predstavljaju podoban instrumentalni okvir za sprovođenje politike asimetričnog paternalizma. Odustajanjem od mehanicističkog poimanja procesa ekonomskog odlučivanja i insistiranjem na empirijski utvrđenim podacima o bihevioralnim anomalijama i psihološki uslovljenim devijacijama $u$ odnosu na model racionalnog izbora, državi se upućuje poruka o potrebi izrade pravila i propisa s namerom da se ublaži stepen neracionalnosti odluka o upotrebi resursa.

Osnovu istraživačkog pristupa ovog rada predstavljaće teorijska, strukturna analiza predmeta istraživanja na bazi elaboracije dostupnih izvora. To znači da će u cilju testiranja navedene hipoteze biti korišćena empirijska istraživanja različitih autora koji su se bavili ovom problematikom. Potom će se kombinacijom analitičke deskripcije i kvalitativne ekonomske analize doći do generalnih zaključaka u vezi sa postojanjem iracionalnih formi ekonomskog ponašanja i potreba za nekom vrstom angažovanja države na planu sprovođenja politike asimetričnog paternalizma.

Rad je strukturiran u četiri sekcije. Nakon uvoda, razmatraće se osnovna obeležja bihevioralnih modela, s posebnim osvrtom na ontološku relevantnost pretpostavki o jednorodnosti/ raznorodnosti ekonomske sredine i određenom stepenu komplementarnosti ciljeva države i ekonomskih subjekata. U posebnoj sekciji rada, biće reči o alternativnim shvatanjima ontologije koja se, shodno predmetu istraživanja rada, tiču nivoa racionalnosti ekonomskih subjekata, modela ekonomskog odlučivanja i razumevanja načina funkcionisanja ekonomskog okruženja. Evaluacija pomenutih razlika između mainstream ekonomije i sporednih tokova ekonomske misli uvažiće kako logičke, tako i empirijske kriterijume procene relevantnosti i održivosti alternativnih tumačenja. U trećoj sekciji rada biće reči o bihevioralnoj ekonomiji i insistiranju njenih predstavnika na tome da stvarnost obiluje primerima iracionalnog ponašanja, što se prevashodno dovodi u vezu sa brojnim psihološkim ograničenjima i anomalijama. Praktičan značaj identifikacije ontološke strukture bihevioralnih modela s aspekta njihove instrumentalističke podrške osmišljavanju mera asimetričnog paternalizma biće predmet analize u četvrtoj sekciji rada. U zaključku rada, opredeliće se stav o postavljenoj hipotezi, kao i nekim otvorenim pitanjima značajnim za buduća istraživanja. 
OSNOVNE KARAKTERISTIKE BIHEVIORALNIH MODELA U

\section{MAKROEKONOMSKOM KONTEKSTU}

Odnos između ekonomske realnosti i njene prezentacije u nauci je izuzetno složen. Za ekonomsku ontologiju, posebno delikatan problem je ontološki status pojedinaca i društva. Na jednoj strani postoji koncepcija atomističke društvene ontologije (Zwirn, 2007), prema kojoj su preferencije i osobine pojedinaca unapred oblikovane i nezavisne od konteksta. Na drugoj strani se afirmiše ontološka koncepcija koja priznaje međuzavisno i međusobno delovanje pojedinaca, vrednujući uticaj institucija na ekonomsko ponašanje. Time se, u okviru ovog pravca socijalne ontologije, individualna i društvena svojstva sistema proglašavaju jednako relevantnim, što otvara i pitanje utvrđivanja odnosa, uzajamnog delovanja i potencijalne saglasnosti ciljeva države i ekonomskih aktera.

U kontekstu tumačenja pomenutih odnosa poseban značaj imaju dva aspekta ekonomske realnosti: stepen jednorodnosti ekonomske sredine i komplementarnost ciljeva ekonomskih subjekata i države (Likhachev, 2013, 789). Jednorodnost ekonomske sredine pretpostavlja da svi ili većina ekonomskih subjekata koriste identičnu proceduru donošenja odluka, koja može biti predstavljena u vidu opšteg bihevioralnog modela. U tom slučaju, određivanje optimalne strategije državne regulacije suštinski se uprošćava, budući da reakcija ekonomskih subjekata isključivo zavisi od nijhove funkcionalne uloge $\mathrm{u}$ okviru sistema. Kada se na ponašanja ekonomskih aktera gleda kao na homogena, identična nastojanja usmerena na ostvarivanje maksimizirajućih ciljeva, sprovođenje državne regulacije zavisi od pretpostavljenog stepena komplementarnosti ciljeva države i ekonomskih subjekata. Ukoliko se misli da je taj stepen prilično visok, to se zadatak države svodi na traženje optimalne varijante regulacije, kojom se istovremeno maksimiziraju kako njena ciljna funkcija tako i ciljne funkcije ekonomskih subjekata. Ukoliko je stepen komplementarnosti ciljeva neznatan, državi preostaje da stvori sistem kontrastimulacija (koje ograničavaju mogućnosti maksimizacije ciljnih funkcija ekonomskih subjekata), kako bi ublažila dejstvo ograničavajućih faktora za maksimizaranje sopstvene ciljne funkcije.

Ukoliko se pretpostavi raznorodnost ekonomske sredine, tj. dopusti mogućnost postojanja različitih modela donošenja odluka, logično je očekivati različite rakcije ekonomskih aktera na mere koje osmišljava i sprovodi država. Tada je moguće ekonomske subjekte grupisati ne samo prema funkcionalnim obeležjima, veći $i$ po modelu odlučivanja i potencijalnim reakcijama na aktivnosti i mere države. U tom slučaju, izbor optimalne makrekonomske strategije zavisi od strukturnih karakteristika nehomogene ekonomske sredine, odnosno, od pretpostavljenog nivoa međusobne neusaglašenosti delovanja ekonomskih aktera.

\section{ALTERNATIVNA SHVATANJA ONTOLOGIJE U EKONOMIJI}

Pretpostavka o potpunoj jednorodnosti ekonomske sredine jedno je od ključnih obeležja neoklasične ekonomske teorije, ali i svim njenim modifikacijama oličenim u monetarizmu, školi racionalnih očekivanja, teoriji realnog ekonomskog ciklusa i dr. Pomenuta jednorodnost bazira se na univerzalnom principu maksimizirajuće racionalnosti, opisanom u modelu reprezentativnog agenta. Suština pristupa je da se $u$ okviru neoklasične teorije polazi od pretpostavke o reprezentativnim individuama ili reprezentativnim firmama, formiranim na osnovu agregiranja informacija o načinu odlučivanja (Simon, 1992, 41). Pri tom se na odvijanje i proceduru ekonomskog delovanja ne gleda iz perspektive komplementarnosti ciljeva ekonomskih aktera i države. Umesto toga, na intervenciju države se gleda kao ometajući faktor dostizanja optimalnih ekonomskih parametara $u$ dugom roku. Odnos između države i privrednika tretira se kao vrsta antagonističke igre, u kojoj je dobitak jedne strane ravan gubitku druge (Likhachev, 
2013, 790), što, po pravilu, rezultira sniženjem društvenog blagostanja u celini. Zato se predlaže minimizacija diskrecione uloge države $u$ korist izgradnje institucionalnog relulatornog okvira i vođenja stabilizacione politike.

Za neoklasičnu teoriju princip racionalnosti ima analitičko i normativno značenje, koje se ispoljava ne samo prilikom opisa i objašnjenja posmatranih fenomena, već i prilikom ocene alternativnih opcija terminima dobro/loše. Tvrdnja da se pojedinci uvek ponašaju racionalno, u neraskidivoj je vezi sa pretpostavkom da oni znaju šta je $u$ njihovom najboljem interesu, i da ne postoje oni koji to bolje znaju od njih. Otuda je ova pretpostavka i normativna i pozitivna: pojedinci treba da deluju i uvek deluju u svom najboljem interesu. Na taj način aktuelizuje se pitanje kako treba odlučivati, što je, između ostalog, polovinom XX-og veka, uticalo na pojavu normativne teorije odlučivanja. Za razliku od deskriptivne teorije, čiji je cilj opisivanje onoga što jeste, normativna teorija odlučivanja bavi se konceptom racionalnosti i logikom donošenja odluka, i to onakvim kakvi bi oni trebalo da budu (Milićević, Pavličić i Kostić, 2007, 147).

Za razliku od neoklasične ekonomske teorije, alternativni tok shvatanja ontologije polazi od pretpostavke o raznorodnosti ekonomske sredine. Prema ovom gledištu, na individue se ne može gledati kao na uniformne agente koji se ne razlikuju u pogledu individualnih preferencija, zahteva i težnji. Umesto toga, insistira se na činjenici da su oni skloni neidentičnom razumevanju načina funkcionisanja ekonomskog okruženja, te da ih karakteriše nejednak nivo edukativne i tehnološke osposobljenosti. Pojedinci nisu slični ni u pogledu preferencija, ni u smislu mogućnosti, iz čega sledi zaključak da je za objašnjenje ekonomskog ponašanja potrebno više o postulata racionalnosti (Blaug, 1992, 232). Realne okolnosti upućuju na to da je za razumevanje individualnog ponašanja, pored navedenog, potrebno uvažiti uticaj navika, tradicije, inercije, imitacija i sl.

$\mathrm{Ne}$ dovodeći $\mathrm{u}$ pitanje generalnu racionalnu usmerenost ljudi, treba biti oprezan kada je reč o opravdanosti teze o univerzalnom egoizmu svojstvenom tzv. homoekonomikusu neoklasičnog pristupa. Umesto nje, realnija je pretpostavka o stvarnom bitisanju tzv. relacijskog čoveka, koji ni u kom slučaju nije apsolutni nosilac beskompromisnog egoizma. Tako, recimo, ima mišljenja da zahtev za neprekidnim i neretko surovim procesom uvećavanja kapitala ne dolazi samo kao produkt racionalne logike, već da su vlasnici kapitala na to prinuđeni, pre svega, zbog snažne konkurencije svojstvene otvorenim tržištima. Gledano iz porodične perspektive, nesporno je da neka domaćinstva isključivo teže uvećanju svog materijalnog bogatstva. Za neka druga, pak, izvor zadovoljstva jeste idiličan i relativno skroman način života, treća su posvećena ostvarivanju širih društvenih interesa, dok ima i takvih koja smatraju da svojim altruističkim žrtvovanjem vrše određenu socijalnu misiju. Iz svega rečenog proizilazi da ljudi imaju sposobnost, a često i sklonost, da razumeju i reaguju na tuđe nevolje, a da na polju ekonomskog delovanja pored racionalnih motiva uvaže i neke druge norme ponašanja poput poverenja, simpatije, empatije i sl. (Олейник, 1999, 140).

Ideja racionalnosti $u$ neoklasičnom modelu počiva na pretpostavci da se ekonomsko delovanje odvija na temelju posedovanja svih potrebnih informacija neophodnih za proces ispravne ocene alternativnih izbora i njihovih posledica. Međutim, u praksi se ponašanje usmereno na izbor najpogodnijih načina i sredstava za ostvarivanje zadatih ciljeva suočava sa brojnim teškoćama. Ljudi, nažalost, žive u svetu neizvesnosti, zbog čega se otvara pitanje donošenja odluka u okolnostima odsustva konačnog znanja o njihovim posledicama. Izvesno je da ljudi u uslovima brojnih organičavajućih faktora razrađuju subjektivne modele izbora koji nemaju uporište u obilju savršenih informacija. Nepostojanje jedinstvenog modela odlučivanja dodatno uvećava neizvesnost, zbog čega se među ekonomskim akterima ispoljava različita sklonost ka preuzimanju rizika u zavisnosti od subjektivnih doživljaja konkretnih sadržaja iz spoljašnje sredine. Nepostojanost subjektivnih percepcija o zadovoljavajućim ekonomskim ishodima 
povezana je sa mnoštvom mogućih procedura odlučivanja čija primena dovodi do različitih nivoa racionalnosti. Ako neki pojedinac želi da bude racionalan, on mora odgovornije pristupiti izboru procedure odlučivanja u smislu detaljnije analize i obrade potrebnih informacija. Na drugoj strani, pojedinac koji nema dovoljno vremena i novca služiće se manje složenim algoritmima. Ispostavlja se, dakle, da je ostvarenje potpune racionalnosti ekstremni slučaj koji u postupku odlučivanja zahteva primenu savršenog algoritma odlučivanja sa uvažavanjem ogromnog broja ograničavajućih faktora. U svim ostalim slučajevima krajnji rezultat jeste posledica primene nesavršenih algoritama odlučivanja, koji predstavljaju praktično ostvarivanje ograničene racionalnosti.

Iako pokretanjem pitanja racionalnosti rizikuju da se nađu pod optužbom da napuštaju ekonomsku nauku (Hodgson, 1988, 74), oni koji to čine imaju razložna objašnjenja kojima potkrepljuju relevantnost svojih istraživačkih nastojanja. Među njima treba posebno istaći pragmatično tumačenje, po kome je tek na temelju osporavanja maksimizirajuće racionalnosti moguće preduzeti izvesne korake kako bi se delovanje ekonomskih aktera usmerilo u pravcu podsticanja racionalnosti. Na toj liniji razmišljanja se, između ostalog, može objasniti komplementarnost ciljeva države i ekonomskih aktera. Kada se prizna da ljudi mogu činiti izbore koji nisu konzistentni sa njihovim interesima, relevantno postaje mišljenje po kome država može pomoći pojedincima da donose bolje i kvalitetnije odluke.

Imajući $u$ vidu brojna negativna iskustva sa angažovanjem države, kao i česta izostajanja očekivanih efekata po osnovu njenih mera, čini se da posebnu pažnju zavređuje objašnjenje državnog intervencionizma $u$ okviru institucionalizma $i$ bihevioralne ekonomije. Za razliku od neoklasičara, po kojima ljudi kao živa bića imaju urođene individualne preferencije i motive, institucionalisti smatraju da korene čovekovih akcija treba tražiti u delovanju institucionalne strukture (Dugger, 1979, 903). To implicira da institucije nisu samo puka ograničenja koje racionalni akter uzima u obzir prilikom svog optimizirajućeg kalkulusa, već su, kao bazični regulator odnosa između ljudi, zapravo, pretpostavka racionalnosti (Олейник, 1999, 140). Konkretnije preporuke u vezi sa prevazlaženjem problema prouzrokovanih neracionalnim delovanjem nudi bihevioralna ekonomija.

Bihevioralna ekonomija polazi od stava da se misaoni procesi i odlučivanje ljudi zasnivaju na dve vrste procedura: intuiciji i rezonovanju, koji se označavaju i kao Sistem 1 i Sistem 2. Operacije u Sistemu 1 su brze, automatske, asocijativne, ne zahtevaju naprezanje i neretko su emotivno obojene. Njima upravljaju navike, i teško ih je menjati. Operacije Sistema $2 \mathrm{su}$ spore, serijske, zahtevaju napor i njima se svesno upravlja. One su relativno fleksibilne i podložne pravilima. Većina odluka produkt je intuitivnog mišljenja, s obzirom na to da ljudi nisu naviknuti da ulažu preveliki misani napor prilikom odlučivanja. Prema modelu racinalnog ponašanja, čovekov kognitivni sistem zapravo je mešavina pomenuta dva mehanizma: on poseduje nepogrešivost Sistema 2 i niske troškove koji su prednost intuitivnog mišljenja. Bihevioralna ekonomija, zadržavajući navedenu deskripciju ljudskog saznajnog aparata, ukazuje na njegove limite i manjkavosti u domenu ljudskog odlučivanja u realnim situacijama (Kahnemann, 2003a; Stefanović, 2016). Ljudsko ponašanje, zapravo, pokazuje sistematske devijacije $u$ odnosu na konvencionalni model ekonomske ortodoksije.

Tokom sedamdesetih godina XX-og veka, D. Kahnemann i A. Tversky pokrenuli su istraživanja usmerena ka ispitivanju odstupanja stvarnih verovanja i izbora ljudi u odnosu na one koje predviđa model racionalnog izbora. Preciznije, krenulo se sa kritičkom rekonsideracijom osnovnih postavki konvencionalne ekonomske teorije: da su agenti racionalni i sebični i da imaju stabilne preferencije (Kahnemann, 2003b, 162). Iako su njihovi doprinosi bili namenjeni psihološkoj naučnoj zajednici, izazvali su značajnu pažnju ekonomske teorije. 
Tehničko-metodološki oslonac pomenuti pravac nalazi u eksperimentima, mada se $u$ novije vreme koriste i terenski eksperimenti i kompjuterske simulacije i sl. U domenu metoda, postoje značajne sličnosti sa srodnom istraživačkom orijentacijom, poznatom kao eksperimentalna ekonomija. Međutim, za razliku od bihevioralne ekonomije, koja ima razuđenije metodološke tehnike, potonji pravac sebe, zapravo, identifikuje sa primenom eskperimenta kao metoda (Camerer \& Loewenstein, 2004, 6). Između bihevioralne i eksperimentalne ekonomije postoji još jedna značajna razlika. Bihovioralna ekonomija detektuje odstupanja od modela racionalnog izbora $\mathrm{u}$ realnom svetu $\mathrm{u}$ nameri da se stvarno ponašanje aktera u konačnom uskladi sa njegovim preskripcijama. Za eksperimentalne ekonomiste, ukoliko eksperiment pokaže neslaganje ponašanja pojedinaca sa neoklasičnim modelom, to ne znači da je ono suštinski neracionalno, već da se, zapravo, pošlo od pogrešnog modela racionalnosti. Iako nije racionalno sa aspekta modela racionalnog izbora, ponašanje pojedinaca je racionalno $u$ njihovom ekonomskom okruženju. Njihovo ponašanje nije neoklasično racionalno, već ekološki racionalno (Smith, 2005, 135-150; Stefanović, 2016).

\section{BIHEVIORALNE GREŠKE}

Bihevioralna ekonomija ne interpretira ekonomsko ponašanje u skladu sa standardnim modelom racionalnog izbora. Njeni predstavnici insistiraju na tome da stvarnost obiluje primerima iracionalnog ponašanja, što se prevashodno dovodi u vezu sa brojnim psihološkim ograničenjima i anomalijama. $S$ tim $u$ vezi, najviše se pominju bihevioralne nesavršenosti koje se odnose na nedoslednost $u$ pogledu diskontovanja, promenljivost psihološkog i emotivnog stanja, zavisnost od konteksta, nedostatak samokontrole, preveliki optimizam, usmerenost na status quo i sl. (Rizzo \& Whitman, 2009, 932-943).

Hiperbolično diskontovanje: Poznato je da pojedinci preferiraju sadašnja dobra, i da su zbog toga spremni da žrtvuju veću količinu budućih dobara kako bi u sadašnjem vremenu trošili manju količinu istih (Wright \& Ginsburg, 2012, 1043). Proporcije takve konverzije, međutim, plod su subjektivnih normi vezanih za vrednovanje vremena u pogledu prednosti uživanja u tekućoj potrošnji. Kako se subjektivno oblikovane procene mogu značajno razlikovati među ljudima, to se može dogoditi da kod donošenja odluka o upotrebi resursa pojedinci polaze od različitih stopa diskontovanja. Tako je, na primer, kod strpljivih osoba, diskontna stopa, po pravilu, niska, dok je kod onih nestrpljivih, ona uglavnom visoka. Izrazitu nestrpljivost prati visoka kratkoročna stopa diskontovanja, kada se donose one odluke za koje se pretpostavlja da će odmah doneti izvesne koristi, a da će troškovi koji prate proces odlučivanja dospevati postepeno tokom vremena. Takav pristup može rezultirati negativnim pojavama kao što su odlaganje donošenja važnih odluka, formiranje portfolija međusobno isključivih finansijskih instrumenata (kada, recimo, pojedinci koriste kreditne kartice po kojima plaćaju visoke kamatne stope, dok istovremeno kupuju hartije od vrednosti sa nižim prinosima), preveliko zaduživanje, niska štednja i sl. (Kapeliushnikov, 2015, 87).

Psihološko stanje: Na proces donošenja odluka veliki uticaj ima psihološko stanje pojedinaca u kojem se oni nalaze, a što može rezultirati efektima koji u značajnoj meri odstupaju od onoga što bi ostvarili da su se rukovodili elementarnim normama racionalnog ponašanja. U nekim afektivnim, biološki gorućim stanjima, individue su sklone donošenju nepromišljenih odluka, za koje će vreme pokazati da su bile pogrešne i skupe, kao i da je nakon njihovog donošenja nemoguć povratak na staro (Camerer, Issachoroff, Loewenstein, O'Donoghue \& Rabin, 2003, 1238; Rizo \& Whitman, 2009, 929). Individue obično tada precenjuju potencijalne kratkoročne koristi, ignorišući pri tom moguće dugoročne štete i visoke troškove donošenja takvih odluka. Tako, recimo, preduzetnici početnici $u$ stanju razočarenja prouzrokovanog početnim finansijskim rezultatima i bojazni da neće uspeti da se izbore sa konkurencijom, 
mogu doneti odluku o okončanju poslovanja i zatvaranja preduzeća, što se $u$ dugom roku može ispostaviti kao pogrešan potez.

Efekat dostupnosti: Radi se o greškama koje se javljaju kada pojedinci pridaju previše značaja lako dostupnim ili ključnim informacijama. Poznato je da se prva ili poslednja iskustva, hronološki gledano, lakše prizivaju u sećanje od onih koja su se dogodila između njih (MekFadden, 2003, 186187). Na primer, ako je nedavno došlo do likvidacije poznate kompanije, ili, pak, štrajka u nekom velikom preduzeću, mnogima će izgledati da su bankrotstva i štrajkovi u poslednje vreme uzeli maha. To, međutim, ne mora imati potporu u statističkim podacima, pa bi neka potpunija istraživanja možda dovela do činjenice da je toga oduvek bilo, te da to oslikava kompleksnost tržišta i načina njegovog funkcionisanja (Petrović, 2014, 199).

Greške povezane sa održavanjem status quo-a: Radi se o sklonosti ljudi da imaju određene rezerve prema svemu onome što je novo, čak i onda kada im to može doneti značajne koristi, odnosno, kada su troškovi povezani sa napuštanjem starog relativno niski. Jedan od razloga opreznog vrednovanja bilo kakvih promena jeste taj što se ljudi prilično emotivno odnose prema svom radu i rezultatima svoga delovanja, što, pak, nije slučaj kada isti nisu akteri posmatranih radnji i dešavanja. Drugi razlog tiče se oklevanja, tj. odlaganja donošenja važnih odluka za buduća vremena. Konačno, ljudi imaju averziju prema gubitku, zbog čega su skloni da prilikom poređenja ekvivalentnih iznosa, relativno veću negativnu vrednost pridaju potencijalnim troškovima, nego što su spremni da pozitivno ocene potencijalne koristi (Kapeliushnikov, 2015, 88).

Greške povezane sa optimizmom i pesimizmom: U zavisnosti od toga da li su ljudi previše samouvereni, ili ih, pak, karakteriše nedostatak samopouzdanja, nastaju greške koje se $\mathrm{u}$ okviru bihevioralne ekonomije dovode $u$ vezu sa optimizmom i pesimizmom. Greške uzrokovane optimističkim razmišljanjem nastaju kao posledica ignorisanja verovatnoće nastupanja neželjenih događaja (Wright \& Ginsburg, 2012, 1043), što pojedincu može naneti često nepopravljive štete. Tako, recimo, optimista može preuzeti suviše veliki rizik, ulažući sredstva $\mathrm{u}$ hartije od vrednosti sa visokom stopom prinosa. Međutim, upravo je sekundarno tržište kapitala, zbog svoje dinamike i pokretljivosti, tipično područje na kome vlada visok nivo neizvesnosti, čega pojedinac mora biti svestan prilikom donošenja odluke o kupovini hartija od vrednosti. S druge strane, greške po osnovu pesimizma karakteristične su za ljude nesigurne u sebe, koji su zbog toga skloni preuveličavanju verovatnoće nastupanja neželjenih događaja. Posledica toga jeste suvišna opreznost, što, po pravilu, rezultira izbegavanjem bilo kakvog rizika kada je u pitanju ulaganje sredstava.

Zavisnost od konteksta: Ova anomalija javlja se $\mathrm{u}$ dva različita oblika. Jedan od njih poznatiji je kao efekat uokvirenja, kada se odluke donose na osnovu uticaja manje važnih karakteristika određene situacije ili pojave. Prema ovome, individua je sklona izboru određene opcije u zavisnosti od redosleda upoznavanja sa njima i od načina na koji je izbor predstavljen. Primera radi, više ljudi podržava ekonomsku politiku onda kada se u obrazloženju predviđenih mera ističe značaj stope zaposlenosti, nego u slučaju kada se u prvi plan ističe stopa nezaposlenosti (Druckman, 2001). Kada se radi o konkretnom preduzeću, jedno mišljenje imaće radnici kada im se saopšti da će zahvaljujući nabavci savremene opreme doći do porasta produktivnost rada, a verovatno nešto drugačiji stav kada se kaže da je cilj kupovine nove opreme snižavanje troškova rada. Zavisnost od konteksta možemo posmatrati i kroz mogućnost ocene dostupnih alternativa na osnovu poređenja sa nekim referentnim vrednostima, iznosima ili količinama. Pri tom referentna tačka sa kojom se vrši određeno poređenje može biti rezultat ličnog iskustva, ali i nekih faktora koji dolaze iz okruženja. Tako, recimo, ukoliko svoj uspeh meri u apsolutnom smislu, vlasnik preduzeća može biti nezadovoljan poslovanjem firme, smatrajući da nije postigao željene rezultate. Međutim, u drugom 
kontekstu, na osnovu komparacije sa poslovnim rezultatima firmi iz svog okruženja, on čak može biti i relativno zadovoljan ostvarenim (Petrović, 2014, 199).

\section{REALISTIČNOST BIHEVIORALNIH MODELA U FUNKCIJI PATERNALISTIČKIH MERA I INTERVENCIJA DRŽAVE}

Identifikacija bihevioralnih anomalija potvrđuje da se ekonomsko ponašanje često kosi sa pretpostavkom racionalnosti i hipotezom maksimizirajućeg ponašanja. Zato treba posebno vrednovati nastojanja da se ustaljeni koncept shvatanja o racionalnom ekonomskom delovanju zameni novim realističnijim opisom ljudskog ponašanja koji se zasniva na pretpostavci o ograničenoj racionalnosti. Otuda i potreba za razradom bihevioralnih modela sa većim instrumentalističkim značajem, u smislu podrške donošenju državnih mera usmerenih na ublažavanje problema prouzrokovanih neracionalnim aspektima odlučivanja. Naime, pretpostavke bihevioralnih modela, zasnovane na empirijski utvrđenim činjenicama o manje ili više racionalnim/neracionalnim formama ponašanja i različitim procedurama donošenja odluka, pružaju snažnu instrumentalističku podršku za osmišljavanje paternalističkih mera i intervencija. Samo priznanje da ljudi mogu činiti izbore koji nisu konzistentni sa njihovim najboljim interesima, doprinosi razvoju ideje o tome da paternalistički orijentisana država može pomoći pojedincima da donose kvalitetnije odluke.

Instrumenti državne politike predstavljaju složenu kombinaciju zakonodavnih i administrativnih zabrana, poreza, pružanja potrebnih informacija, kao i utvrđenih načina ubeđivanja i manipulisanja arhitekturom izbora. Među pomenutim formama državne intervencije u proces donošenja individualnih odluka, za najsnažniju slovi ona kojom se uvode eksplicitne zabrane i ograničanja ekonomskog izbora. Ograničavanje individualnog ponašanja opravdano je onda kada je neracionalnost ekonomskih subjekata toliko izražena, da je njeno ispravljanje pomoću mekih paternalističkih mera gotovo nemoguće. S tim u vezi, predlaže se donošenje zakona u svim oblastima u kojima postoji visok rizik u pogledu mogućnosti iracionalnog postupanja ekonomskih subjekata. Primera radi, moguće je uvođenje poreza na alkoholna pića, pušenje, hazardne igre, nezdravu hranu i sl. (O' Donoghue \& Rabin, 2003, 190-91).

Povoljnije rešenje $u$ odnosu na direktna ograničenja i zabrane je ono koje počiva na podržavanju mera tzv. asimetričnog paternalizma, suštinski povezanog sa pretpostavkama o raznorodnosti ekonomske sredine i komplementarnosti ciljeva države i ekonomskih subjekata. Naime, asimetrični paternalizam ostvarenje ekonomskih ciljeva dovodi $u$ vezu sa različitim procedurama odlučivanja i njima svojstvenim nivoima racionalnosti (Thaler \& Sunstein, 2008, 9). Problemi odlučivanja posebno su izraženi u slučajevima kada je neophodno doneti kompleksne odluke. Pojedinci tada mogu imati problema u vezi sa razumevanjem situacije u kojoj se nalaze, zbog čega na stimulanse iz okruženja ne reaguju na isti način. Sumnja u to da svi ljudi uvek, i, po pravilu, donose odluke koje su u njihovom najboljem interesu (Camerer et al, 2003, 1217), praćena je idejom o tome da treba pomoći ljudima kako ne bi delovali na sopstvenu štetu. U skladu s tim, sazrelo je mišljenje po kome angažovanje države treba usmeriti na predupređenje grešaka manje racionalnih pojedinaca, dok, istovremeno, tim merama ne bi trebalo nametati troškove onima koji odluke donose na bazi primene savršenijih algoritama odlučivanja, uz uvažavanje velikog broja potrebnih informacija. Zadatak asimetričnog paternalizma je, dakle, da blago usmerava ponašanje pojedinaca ka racionalnom modelu, zahvaljujući čemu bi manje racionalne individue bile stimulisane da unaprede svoje izbore, dok se, istovremeno, ne bi nanosila šteta racionalnim pojedincima (Camerer et al, 2003, 1219). Cilj nije promeniti ponašanje, već ga usmeriti kako bi ono na najbolji mogući način dovelo do realizacije individualnih interesa.

Kao ilustrativan primer asimetričnog paternalizma i selektivnog ublažavanja neracionalnih odluka može se navesti zakonsko utvrđivanje tzv. perioda 
hlađenja, u formi dveju mogućih alternativa (Camerer et al, 2003, 1240). Prva alternativa pojedincima dopušta mogućnost da odlože donošenje određenih odluka nakon perioda hlađenja. Druga opcija tiče se donošenja neposrednih odluka o izvršenju ekonomskih transakcija, uz mogućnost da tokom perioda hlađenja dođe do promena istih. Uzmimo primer da je utvrđena mogućnost trodnevnog perioda hlađenja kada je u pitanju kupovina novog automobila. Prva opcija je da pojedinac, kada potpiše ugovor o kupovini automobila, može da sačeka, recimo, tri dana, pre nego što isti preuzme (za to vreme može promeniti mišljenje) - primer ex ante perioda hlađenja. Druga mogućnost je da preuzme automobil odmah, s tim da ga može vratiti u roku od tri dana - primer ex post perioda hlađenja. Zahvaljujući ovoj meri, racionalnim pojedincima se nameću minimalni troškovi - troškovi odlaganja kupovine automobila za nekoliko dana. Istovremeno, odnosni period hlađenja štiti one manje racionalne koji odluke donose $\mathrm{u} \mathrm{t} \mathrm{v}$. vrućem stanju.

Dokaz o tome koliko asimetrični paternalizam može biti od pomoći u proceni efikasnosti državnih mera i politika, predstavlja i koncept podrazumevanih opcija (Thaler \& Sunstein, 2008). Smisao njihovog korišćenja je $\mathrm{u}$ tome da pomogne pojedincima da prevaziđu dvosmislene situacije karakteristične za donošenje važnih odluka. Empirijski je utvrđeno da većina ljudi više pažnje posvećuje sadašnjoj situaciji i aktuelnoj potrošnji, žrtvujući u značajnoj meri zadovoljenje budućih potreba. Zato je, umesto slobode izbora po pitanju izjašnjavanja u vezi dobrovoljnog izdvajanja dela dohotka za penziono osiguranje, logičnije prozvati državu da izvrši izbor za i umesto pojedinca. Dobro poznata varijanta $\mathrm{u}$ tom smislu, prisutna $\mathrm{u}$ mnogim nacionalnim zakonodavstvima, jeste ona koja se odnosi na automatsko učešć u planovima štednje (Rizo \& Whitman, 2009, 914; Thaler \& Sunstein, 2003, 1172), čime se isključuju greške povezane sa nedoslednošću, slabošću volje, hiperboličnim diskontovanjem itd. Učěšce po automatizmu, pre svega, polazi od problema nedoslednosti tokom vremena, što ukazuje na potrebu obavezivanja ljudi da se u budućnosti drže utvrđenih planova. U slučaju štednje na račun penzionih fondova, to zahteva pronalaženje načina da se obezbedi saglasnost radnika da mu se od plate odbija deo novca pre nego što mu dođe u ruke. Tako se novac polaže na račun penzionog fonda, čiji je zadatak da ga u njegovo ime investira.

Jedan od instrumenata asimetričnog paternalizma tiče se i obaveznog objavljivanja određenih informacija prilikom zaključivanja vrednih ugovora, povezanih sa, na primer, kreditiranjem, hipotekom, zakupom, kao i kod kupovine visokorizičnih dobara i usluga. S tim u vezi, postoji uverenje da su prodavci proizvoda štetnih po zdravlje, dužni da građanima pruže detaljne informacije o određenim rizicima (sa objašnjenjima, statističkim pokazateljima i tome slično) (Kapeliushnikov, 2015, 93). Politika obaveznog objavljivanja informacija naročito je delotvorna kod kreditiranja potrošača. Budući da su u finansijskoj sferi pogrešna ponašanja široko rasprostranjena, te da je njihova cena visoka, preporuke su da treba adekvatno informisati potrošače o svim bankarskim proizvodima. Pri tom, potrebu za informisanjem ne treba svesti samo na ispunjavanje opravdanih zahteva za otkrivanjem svih relevantnih informacija vezanih za proces kreditiranja. Još važnije je podržati zaključivanje kreditnih ugovora, u kojima će, umesto implicitnih kreditnih klauzula, prednost imati obavezni elementi standardnih bankarskih proizvoda.

Polazeći od toga da država raspolaže diskrecionim pravom uspostavljanja formalnih institucija i osmišljavanja paternalističkih mera i intervencija, njena uloga u kontekstu ekonomskog i društvenog razvoja može se smatrati ključnom (Petrović, 2015, 353). Usled nagomilanih socijalnih i ekonomskih problema i sporog prihvatanja tržišnih normi ponašanja, čini se da pred državnim i političkim aparatom Republike Srbije (RS) nalaze ogromni zadaci u oblasti institucionalnog inženjeringa, koji će verovatno biti od uticaja i na modele ponašanja domaćih aktera. Svojevrstan okvir takvog reformskog poduhvata je i proces pridruživanja RS Evropskoj uniji (EU). 
Imajući $\mathrm{u}$ vidu izazove sa kojima se RS suočava $\mathrm{u}$ procesu pridruživanja EU, smatra se opravdanim da se u programu Vlade RS identifikuju ključni razlozi neracionalnog ponašanja ekonomskih aktera, shodno potrebi da se, u osmišljavanju i koncipiranju aktivnosti u pogledu ispunjavanja uslova za članstvo u EU, uvažava sklonost učesnika ovog procesa bihevioralnim anomalijama. Naime, nosioci vlasti u RS, posle 2000-te, i veliki broj građana RS ispoljili su, rečnikom bihevioralne ekonomije, sklonost pogrešnim procenama $u$ pogledu nerealnog optimizma i hiperboličnog diskontovanja. Naime, stvarana je atmosfera da se RS nalazi pred vratima EU, te da će "blagodeti" koje donosi članstvo u toj međunarodnoj ekonomskoj integraciji brzo biti ostvarene. Izrazita nestrpljivost praćena je donošenjem odluka za koje se pretpostavljalo da će odmah doneti izvesne koristi, a da će troškovi koji prate proces odlučivanja dospevati postepeno. Tako su neosnovano samouvereni preduzetnici neoprezno posezali za kreditnim zaduživanjem i preteranim investiranjem, ne vodeći računa o mogućim neželjenim efektima. Neopreznom uzimanju kredita bili su skloni i građani RS, što se, pored efekata povezanih sa optimističkim razmišljanjem i hiperboličnim diskontovanjem, može dovesti u vezu i sa uticajem tzv. vrućeg psihološkog stanja. Naime, nakon duge kreditne apstinencije tokom 90-ih godina XX-og veka, dolaskom stranih banaka i ekspanzijom ponude brojnih finansijskih proizvoda, veliki broj građana RS nastojao je da reši stambeno pitanje, obnovi vozni park, ode na letovanje, kupi novi nameštaj, i sl. To su, neretko, činili bez adekvatnih informacija o ceni potrošačkih kredita, troškovima obrade i administriranja, kamatnoj stopi po osnovu korišćenja kreditnih kartica (dozvoljeni i nedozvoljeni minusi), što je, uz brojne skrivene takse i troškove, doprinelo naglom porastu njihove zaduženosti.

Sklonost činjenju bihevioralnih propusta ispoljili su i nosioci vlasti u RS. Prevelika očekivanja u vezi sa finansiranjem projekata iz Pretpristupnih fondova, kao i dobijanja značajnih finansijskih sredstava iz Fonda za regionalni razvoj i Agrarnog fonda EU, uticali su na ishitreno donošenje određenih odluka sa dugoročno štetnim posledicama. U tom kontekstu, potrebno je sagledati i deo mera koje se odnose na liberalizaciju tržišta, na šta se RS obavezala sklapanjem Sporazuma o stabilizaciji i pridruživanju (SSP) sa EU. U skladu sa tim, odnosno, usklađivanje počinje od sledećih područja: zaštita konkurencije i kontrola dodele državnih pomoći (subvencija), pravo intelektualne svojine, javne nabavke, standardizacija i zaštita potrošača. Sa stupanjem na snagu SSP, obaveza usklađivanja se širi i na ostale oblasti. Prelaznim sporazumom, čija je primena počela januara 2009, bilo je predviđeno stvaranje zone slobodne trgovine između RS i EU, u roku od šest godina. Međutim, rok za liberalizaciju trgovine previše je optimistično određen, ne vodeći računa o sposobnostima industrije i poljoprivrede RS da se prilagode slobodnoj trgovini.

Za razliku od raspoloženja koje je vladalo tokom prve decenije XXI-og veka, veliča očekivanja u vezi brzog pristupanja EU značajno su smanjena nakon početka Globalne ekonomske krize, 2008. Utisak je da su građani postali svesni činjenice da članstvo u bilo kojoj međunarodnoj ekonomskoj integraciji ne donosi isključivo pozitivne efekte, već sa sobom nosi i određene obaveze, povećane troškove, a u nekim slučajevima i negativne ishode. Istraživanja sprovedena na osnovu modela R. M. Solow-a, pokazuju da bi troškovi pristupanja RS EU, kako bi domaća privreda dostigla prosečni nivo razvijenosti zemalja EU, iznosili između 110 i 130 milijardi dolara. Troškovi pravnog usaglašavanja sa zakonodavstvom EU bi iznosili oko $10 \%$, a troškovi implementacije oko $20 \%$ pomenute sume. Najveći deo bi trebalo da bude iskorišćen za modernizaciju privrede i infrastrukture. $\mathrm{Za}$ realizaciju tih aktivnosti potrebna je stopa investiranja od 30\% BDP-a, stopa štednje oko 25\% BDP-a, itd. (Marković i Petrović, 2016, 157).

Svest o specifičnostima i visokim troškovima procesa pristupanja EU može rezultirati iracionalnim ponašanjem političkih elita i građana. Položaj privrede RS na putu ka EU može podstaći formiranje uverenja o nekomplementarnosti ciljeva države i stanovništva. Otuda je realno očekivati intenziviranje psiholoških anomalija $u$ vezi sa održavanjem 
status quo-a, pesimističkim razmišljanjima, kao i modelima odlučivanja shodno uticaju manje važnih karakteristika aktuelnih pojava i događaja. Imajući u vidu to da su ljudi u određenim okolnostima skloni da budu sumnjičavi prema onome što je novo, i da su skloni oklevanju i odlaganju prilikom donošenja važnih odluka, ne iznenađuje sve prisutnija rezervisanost građana Republike Srbije prema pristupanju Evropskoj uniji.

\section{ZAKLJUČAK}

U radu je ukazano na značaj modela ponašanja aktera za unapređenje razumevanja stvarnih karakteristika ekonomske sredine. Opšteprihvaćeno stanovište je da ekonomski modeli treba realno da oslikavaju ekonomsko ponašanje i uslove date ekonomske i socijalne sredine. Iako postoji mnogo slučajeva $\mathrm{u}$ kojima su zahtevi pomenute saglasnosti ispunjeni, utisak je da formalni ekonomski modeli često ne nalaze potvrdu $u$ empirijskim istraživanjima. Ključne razloge takvih opservacija, između ostalog, treba tražiti $\mathrm{u}$ održivosti mainstream ontologije, bazirane na jednorodnosti ekonomske sredine i komplementarnosti ciljeva države i ekonomskih subjekata. U skladu s tim su i pretpostavke o univerzalnom principu maksimizirajuće racionalnosti i uniformnoj proceduri ekonomskog odlučivanja, pri čemu se odnos između države i ekonomskih aktera tretira kao vrsta antagonističke igre sa međusobno suprotstavljenim interesima.

Pitanje realne utemeljenosti mainstream ontologije i na njenim osnovama uspostavljene metodologije, otvara prostor za pojavu alternativnih shvatanja ontologije. U tom kontekstu, razmatranje ontološke strukture se usmerava u pravcu razrade bihevioralnih modela koji dovode $\mathrm{u}$ pitanje pretpostavke o potpunoj racionalnosti ekonomskih aktera i homogenoj proceduri donošenja ekonomskih odluka. Razloge takvog gledanja na prirodu ekonomskog ponašanja, između ostalog, valja dovesti u vezu sa brojnim praktičnim dokazima koji ukazuju na to da realno ekonomsko ponašanje često odstupa od maksimizirajućeg delovanja tzv. homo ekonomikusa.

Potenciranje rezultata empirijskih istraživanja o ljudskoj sklonosti ka činjenju bihevioralnih anomalija iniciralo je pojavu oprečnih reakcija ekonomskih teoretičara. Na jednoj strani su oni koji smatraju da je pokretanje pitanja racionalnosti udar na tzv. tvrdo jezgro ekonomske nauke. Na drugoj strani ističe se to kako ukazivanje na snažno prisustvo iracionalnog ponašanja ima svojevrstan instrumentalni značaj, što se može smatrati i važnom porukom ovog rada. Priznanje da ljudi mogu činiti izbore koji nisu konzistentni sa njihovim najboljim interesima postaje snažan argument za uključivanje države $u$ proces izrade mera i propisa kojima bi se unapredila njihova racionalnost. U skladu s tim potvrđena je hipoteza da bihevioralni modeli, bazirani na pretpostavci o raznorodnosti ekonomske sredine i komplementarnosti ciljeva države i ekonomskih subjekata, predstavljaju pogodan instrumentalni okvir za sprovođenje politike asimetričnog patrnalizma.

Zaključci izneti u radu upućuju na potrebu daljeg ispitivanja mogućnosti usavršavanja bihevioralnih modela, vodeći računa o ontološkim karakteristikama konkretnih ekonomskih i socijalnih sredina. S tim u vezi treba podržati sva nastojanja koja za cilj imaju dublju spoznaju i temeljnu analizu procesa donošenja ekonomskih odluka, uključujući i identifikaciju brojnih odstupanja od racionalnih formi ekonomskog ponašanja. Budući da je $u$ radu inicirana rasprava o nekim pojavnim oblicima psiholoških anomalija koje ispoljavanju građani Republike Srbije na putu usvajanja pravila i standarda Evropske unije, realno je očekivati da buduća istraživanja budu usmerena na identifikaciju šireg spektra bihevioralnih anomalija koje prate ekonomsko delovanje na ovim prostorima. Istraživački napori usmereni na detaljnu analizu i objašnjenje eksternih i internih razloga iracionalnog ponašanja mogli bi da predstavljaju pogodnu osnovu za osmišljavanje mera asimetričnog paternalizma, koje bi RS sprovela u okviru strategije institucionalnog prilagođavanja zahtevima tržišne privrede. 


\section{REFERENCE}

Blaug, M. (1992). The Methodology of Economics or How Economists Explain, Second Edition. Cambridge: Cambridge University Press.

Camerer, C., Issachoroff, S., Loewenstein, G., O'Donoghue, T., \& Rabin, M. (2003). Regulation for conservatives: Behavioral economics and the case for asymmetric paternalism. University of Pennsylvania Law Review, 151(1), 1211-1254.

Camerer, C. F., \& Loewenstein, G. (2004). Behavioral economics: Past, present, future. In C. F. Camerer, G. Loewenstein \& M. Rabin (Eds.), Advances in Behavioral Economics (pp. 3-51). New York, NY: Russel Sage Foundation and Princeton University.

Dobusch, L., \& Kapeller, J. (2012). Heterodox united vs mainstream city: Sketching a framevork for interested pluralism in economics. Journal of Economic Issues, 46(4), 1035-1057. doi: 10.2753/JEI0021-3624460410

Dow, S. C. (2008). Plurality in orthodox and heterodox economics. Journal of Philosophical Economics, 1(2), 73-96.

Druckman, J. (2001). Evaluating framing effects. Journal of Economic Psychology. 22(1), 91-101. doi.org/10.1016/S01674870(00)00032-5

Dugger, W. M. (1979). Methodological differences between institutional and Neoclassical economics. Journal of Economic Issues, 13(4), 899-909.

Hodgson, G. M. (1988). Economics and Institutions: A Manifesto for a Modern Institutional Economics. Cambridge, UK: Cambridge University Press.

Kahnemann, D. (2003a). Maps of bounded rationality: Psychology for behavioral economics. American Economic Review, 93(5), 1449-1475. doi: 10.1257/000282803322655392

Kahnemann, D. (2003b). A psychological perspective on economics. American Economic Review, 93(2), 162-168. doi: $10.1257 / 000282803321946985$

Kapeliushnikov, R. (2015). Behavioral economics and the 'new' paternalism. Russian Journal of Economics, 1(1), 81-107. doi: 10.1016/j.ruje.2015.05.004

Lawson, T. (2015). Essays on The Nature and State of Modern Economics. London, UK: Routledge.
Likhachev, M. O. (2013). Ontological problems of modern macroeconomics. Middle-East Journal of Scientific Research, 14(6), 788-794. doi: 10.5829/idosi.mejsr.2013.14.6.2137

Marković, I. i Petrović, D. (2016). Međunarodna ekonomska integracija: Efekti i izazovi članstva. U V. Leković (Ur.), Institucionalne promene kao determinanta privrednog razvoja Republike Srbije (str. 157-173). Kragujevac, Republika Srbija: Ekonomski fakultet Univerziteta u Kragujevcu.

MekFadden, L. D. (2003). Racionalnost za ekonomiste? Ekonomski anali, 156, 169-199.

Milićević, A., Pavličić, D. i Kostić, A. (2007). Odlučivanje u uslovima rizika i teorija izgleda. Psihologija, 40(1), 147-164.

O'Donoghue, T., \& Rabin, M. (2003). Studying optimal paternalism, illustrated by a model sin taxes. American Economic Review, 93(2), 186-191. doi: $10.1257 / 000282803321947029$

Petrović, D. (2014). Behavioral analysis of economic choice: Contribution to improving economic rationality. Facta Universitatis, Series: Economic and Organization, 11(3), 191205.

Petrović, D. (2015). Behavioral economics - The new approach to designing the paternalistic role of the state in the economy. Teme, 39(2), 345-360.

Rizzo, M. J., \& Whitman, D. G. (2009). The knowledge problem of new paternalism. BYU Law Review, 4, 904-968.

Samuels, W. J. (1998). Methodological pluralism. In J. Davis, D. Wade Hands \& U.i Mäki (Eds.), The Handbook of Economic Methodology (pp. 300-303). Cheltenham: Edward Elgar.

Simon, H. A. (1992). Methodological foundations of economics, In J. Lee Auspitz (and other) (Eds.), Praxiologies and the Philosophy of Economics, Series Praxiology (pp. 25-42).

Smith, V. (2005). Behavioral economics research and the foundations of economics. Journal of Socio-Economics, 34(2), 135-50. doi.org/10.1016/j.socec.2004.09.003

Stefanović, Z. (2016). Savremena ekonomska misao: ortodoksni $i$ heterodoksni pravci. Niš, Republika Srbija: Ekonomski fakultet Univerziteta u Nišu. 
Sunstein, C. R., \& Thaler, R. (2003). Libertarian paternalism is not an oxymoron. University of Chicago Law Review, 70(4), 1159-1202.

Thaler, R. H., \& Sunstein, C. (2008). Nudge: Improving decisions about health, wealth, and happiness. New Haven \& London, UK: Yale University Press.

Wright, D. J., \& Ginsburg, D. H. (2012). Behavioral law and economics: Its origins, fatal flaws and implications for liberty. Northwestern University Law Review, 106(3), 10331089.
Zwirn, G. (2007). Methodological individualism or methodological atomism: The case of Friedrich Hayek. History of Political Economy, 39(1), 48-80. doi:10.1215/001827022006-005

Олейник А. (1999). Институционална экономика, Тема 2. Норма как базовый елемент институтов, Лекция 3. Норми: результат рационалъного выбора или абсслолютный детерминант действия? Вопросы эномики, 2, 137-156.

Primljeno 8. aprila 2017, nakon revizije, prihvaćeno za publikovanje 24. aprila 2017. Elektronska verzija objavljena 28. aprila 2017.

Dragan Petrović je redovni profesor na Ekonomskom fakultetu Univerziteta u Nišu, gde je doktorirao iz uže naučne oblasti Opšta ekonomska teorija. Oblasti njegovog naučnog istraživanja su ekonomska metodologija, institucionalna ekonomija, makroekonomska teorija, politička ekonomija.

Zoran Stefanović je vanredni profesor na Katedri za opštu ekonomsku teoriju Ekonomskog fakulteta Univerziteta u Nišu. Izvodi nastavu na nastavnim predmetima: Ekonomske doktrine, Ekonomika tranzicije, Savremene ekonomske teorije, Tranzicija postsocijalističkih privreda. Oblasti njegovog istraživačkog interesovanja su savremene ekonomske paradigme, ekonomika tranzicije i politička ekonomija globalizacije.

Ivan Marković je vanredni profesor na Ekonomskom fakultetu Univerziteta u Nišu, gde je doktorirao u okviru uže naučne oblasti Međunarodna ekonomija. Drži nastavu na nastavnim predmetima Međunarodna ekonomija, Menadžment u spoljnoj trgovini, Međunarodne finansije. Ključne oblasti njegovog interesovanja su međunarodne ekonomske integracije, proces pristupanja Republike Srbije Evropskoj uniji. 


\title{
BEHAVIORAL MODELS IN ECONOMICS AS A FRAMEWORK FOR INDIVIDUAL ADAPTATION TO THE INSTITUTIONAL ENVIRONMENT
}

\author{
Dragan Petrovic, Zoran Stefanovic and Ivan Markovic \\ Faculty of Economics, University of Nis, Nis, The Republic of Serbia
}

Behavioral models are a useful instrument of the analysis of interdependent impacts of the institutional structure and macroeconomic trends. Their role, among other things, is reflected in presenting the advantages and disadvantages of different interpretations of economic reality, associated with the subjective perceptions of the possibilities of the adaptation of economic actors to the requirements of the existing institutional structure. Having in mind the fact that the economic decision-making process is an integral part of macroeconomic and broader social ontology, as well as the different opinions regarding the basic features of behavioral models, the subject of this work is focused on trying to determine their theoretical relevancy and practical foundation. Special attention is paid to the phenomenon of the realism of behavioral models in order to analyze their instrumentalist importance for the implementation of the policy of asymmetric paternalism in conditions of uncertainty.

Keywords: behavioral models, institutional structure, macroeconomics, paternalism

JEL Classification: D03, E03, B29, B41, P29 